Water Resources Management manuscript No.

(will be inserted by the editor)

\title{
Monitoring water use regimes and density in a tourist mountain territory
}

\author{
Martin Calianno • Marianne Milano • \\ Emmanuel Reynard
}

Received: date / Accepted: date

\begin{abstract}
Lack of water use data at the user scale is frequently noted in integrated water management and water demand modelling studies. This situation affects particularly mountain tourist areas, where high seasonal water demand related to the variation of temporary population are rarely documented. Irrigation is also a major water use in moutain territories but is not commonly measured. This paper proposes a framework for local-scale monitoring of seasonal water use behaviours and their territorial inprint. A monitoring strategy was developed to collect water demand data at thin spatio-temporal scales which were analysed using two concepts: (i) the water use regime, describing the dynamics of water uses throughout the year using normalised values, and (ii) the water use density, expressing the territorial footprint of a water use, in terms of unit area. This strategy was applied in the alpine tourist municipality of Montana (Switzerland). A two-year monitoring campaign of irrigation and drinking water uses was carried out combining in-field measurement (water meters) with interviews of water users. The temporal resolution of the collected water use dataset (bi-weekly, daily) was sufficient to assess the specific water demand patterns and the short-term water use peaks responsible for water stress in Alpine tourist regions. It provided the first irrigation monitoring in the area and a classification of drinking water data according to their spatial distribution, the type of building and the permanency of residents. The water use density method gives a new prespective on the spatial intensity of water uses, highlighting the importance of garden irrigation in Montana. Also, the water use regime method identified July as the period of water demand peaking. The monitoring of water uses at such thin temporal scale constitutes the necessary dataset for the creation of water balance models that accurately reproduce the effective water use behaviours.
\end{abstract}

Martin Calianno

Institute of Geography and Sustainability, University of Lausanne, Geopolis Mouline, 1015

Lausanne

E-mail: martin.calianno@unil.ch 
Keywords Integrated water management - Monitoring · Water use regime · Water use density · Drinking water · Irrigation - Tourist mountain territory

\section{Introduction}

In integrated water management studies, the spatial and temporal variability of water uses are more and more implemented in water supply-demand balance at both the regional scale (Collet et al, 2015; Milano et al, 2015) and the catchment scale (Reynard et al, 2014; Fabre et al, 2016). Such approaches evaluate the pressures exerted by climate and society on water resources and the capacity of these resources to meet anthropic and environmental water needs. These works often note the lack of comprehensive knowledge on the dynamics of various water uses in both space and time, at sufficient resolution (Grouillet et al, 2015). Water demand datasets exist at the basin or regional scale and at annual, seasonal or monthly time steps (Romano et al, 2016; Vallès-Casas et al, 2017), but water demand observations at weekly or daily time steps with sufficient spatial resolution (building, end-user scale) need to be developed to identify water stress events happening at small time scales.

This work follows the MontanAqua project (Reynard et al, 2014), which quantified water resources and water demands in the Crans-Montana region (Switzerland) to propose water management strategies according to different climatic and socio-economic scenarios. The MontanAqua project, as many other water management studies in Alpine tourist territories (Paccard, 2010; Saulnier et al, 2011; Klug et al, 2012; Magnier, 2013; Leroy, 2015) was confronted to the lack of data on water uses or their poor spatial and temporal resolution (Bonriposi, 2013). In a more general context, studies on water demand management modelling also point out the limitations in data support, leading to major uncertainties (Nazemi and Wheater, 2015; Haque et al, 2017).

This work addresses two issues concerning water uses in mountain tourist regions. The first one is the high seasonality and the intensity of some water demands. In mountain territories including a tourist resort, drinking water inter-annual demands are highly variable in relation to the alternating tourist seasons. The variation of temporary population (secondary residents, tourists) is causing water demand variability at short temporal scales (daily) due to weekend visitors and longer temporal scales (monthly) along with tourist seasons: winter ski holidays, summer. Moreover, irrigation of pastures, vineyards and private gardens is common in mountain valleys and are seasonal too. Because water resources in mountain areas are also very seasonal, with river low flows occurring during high water demand periods in winter and at the end of summer, situations of water stress can happen at very short time scales. To model and forecast such intense scarcity events, water resources in tourist regions are usually monitored at sufficient temporal time steps (daily, up to hourly), but water uses that are commonly measured annually (Gössling et al, 
2012; March et al, 2015; Morote et al, 2016; Sax et al, 2016) or monthly (RicoAmoros et al, 2009; Vanham et al, 2011; Bonriposi, 2013) need to be studied with a better temporal resolution in order to identify and manage short time scale water scarcity events. The second issue is the lack of available water use data at sufficient temporal resolution necessary to assess such short-term water demand peaks and to validate water demand models, as noted in previous studies (Milano et al, 2013; Collet et al, 2015; Fabre et al, 2016). With respect to drinking water uses, data at the end-user scale in mountain areas are most often at insufficient temporal resolution, because they usually come from annual water billing (Calianno et al, 2017). This situation contrasts with high resolution residential water demand datasets available in large cities using smart metering techniques (Gurung et al, 2016). At the scale of water distribution, data can be available at daily time steps or lower as measurement are usually made at the municipal reservoir output (Gargano et al, 2017). But distribution data only give an averaged image of all water use behaviours: they do not describe the spatial variability of water use inside the municipality, nor the different water demand patterns which are usefull for water management. With respect to irrigation, the MontanAqua project (Reynard et al, 2014) simply could not collect any observed data, as no volumetric monitoring was made on irrigation networks. To face this absence of data, Bonriposi (2013) made withdrawal measurements on irrigation channels, but data at this scale overestimated water demand, as these channels convey running water during the whole irrigation season, whether the water is used to irrigate or not. $\mathrm{He}$ also modelled crops water needs using the FAO CropWat method (Allen et al, 1998), which overestimated water demand as well.

From these issues, two questions are raised:

- What are the different seasonal behaviours of the multiple uses of drinking water and irrigation in a mountain tourist area?

- What is the spatial inprint of these water uses on the territory?

The first objective of this article was to develop a monitoring strategy based on the water use cycle framework (Calianno et al, 2017) to collect weekly water use data at end-user scale and to apply it to a case study, in the Swiss Alps (the municipality of Montana). The second objective was to create conceptual tools for the assessment of water uses: the water use regime describing the seasonality of water demand and the water use density, highlighting the territorial footprint of water use, per unit area (mm).

The next part of this paper presents the study area. The third part describes the methodology used for on-site water use monitoring and defines the concepts of water use regime and density. In the fourth part, the results of monitoring survey are presented and discussed using these two concepts. 
2 Study area: a tourist mountain territory

The water demand of the Alpine municipality of Montana (Valais, Switzerland) is explored because it includes a tourist resort and irrigated lands, leading to highly seasonal uses of drinking water and irrigation (Reynard and Bonriposi, 2012). Montana is located on the south-facing slope of the Rhone River Valley, forming a $4.9 \mathrm{~km}^{2}$ vertical strip that ranges from $519 \mathrm{~m}$ to $1775 \mathrm{~m}$ a.s.l (Fig. 1). The higher end of the municipality (1400-1775 m a.s.l.) includes a part of the Crans-Montana tourist resort (5410 tourist beds). In 2013, 2,398 permanent inhabitants lived in the municipality (source: municipality of Montana). Lower in altitude is the historical village of Montana (1200 $\mathrm{m}$ a.s.l.), which is surrounded by pastures. The village of Corin, surrounded by vineyards, is situated at the lower end (550-800 m a.s.l.). Because of a rain-shadow effect caused by high mountain ranges enclosing the Rhone River Valley, climate is semi-continental, with hot and dry conditions in summer, cold winters and high vertical rainfall gradients (Calianno and Reynard, 2016). Mean annual rainfall ranges from $672 \mathrm{~mm}$ in the vineyards (536 $\mathrm{m}$ a.s.l.) to $692 \mathrm{~mm}$ at the level of Crans-Montana ski resort (1472 m a.s.l) (data: MeteoSwiss, period 1981-2010). A specific irrigation network supplies the lower part of Montana (pastures and vineyards areas), to which the tourist resort is not connected. This is why in the resort drinking water is used to irrigate gardens and lawns (Reynard and Bonriposi, 2012).

Water resource basins withdrawn for Montana's water uses are mapped (Fig. 1a) and the spatial distribution of water uses is described using drinking water use basins (Montana's resort, Montana's historic village, and the villages of Diogne and Corin) and irrigation basins (pastures and vineyard) (Fig. 1b).

\section{Methods}

In this work, the concept of the water use cycle (Calianno et al, 2017) is further developed with a focus on the temporal and spatial variability of water uses. A monitoring campaign was set up in the municipality of Montana on the enduser scale to collect water demand time series. The concept of water use regimes is defined as a standardised framework to analyse the temporal signatures of water uses. In terms of spatial variability, we propose to use values of water demands per unit area to assess the territorial footprint of water demands: the water use density.

\subsection{Monitoring campaign}

The monitoring campaign focused on the utilisation of drinking water and irrigation water in Montana. 
3.1.1 Drinking water distribution dataset collected from the water services

A dataset of municipal drinking water distribution at daily time steps was collected from the municipality. Time series selected for this study range from December 2014 to December 2016 (Fig. 2a).

\subsubsection{Drinking water delivery dataset from the field monitoring}

Field visits were carried every month during two years (2015-2016) to collect water meter data at the building scale: houses, residential and commercial buildings, hotels. These water volumes correspond to the delivery scale of the water use cycle (Calianno et al, 2017). In total, 587 out of the 707 water meters of Montana were monitored. As Montana's water meters are equipped with radio transmitters, data were collected with the radio antenna usually used by the water services for annual billing. Beside remote data acquisition, radio water meters record the amount of water on the day of acquisition and the amount corresponding to the last day of the previous month. Monitoring campaigns were made in the middle of each month, allowing to virtually collect data every two weeks. A smaller sample $(n=390)$ was selected based on data quality (excluding time series with gaps or errors). For privacy reasons, individual time series measured at the building scale were aggregated in water use basins: Montana Resort $(n=168)$, Montana-Village $(n=155)$, Diogne $(n=21)$ and Corin $(\mathrm{n}=46)$. The drinking water delivery dataset was then crossed with the Swiss federal register of housing and buildings (StatBL), which provided the number of dwellings per building, the dwelling surface and the number of permanent residents per dwelling. Water use time series could therefore be classified by type of building :

- house,

- apartment block,

- winery,

- business,

- hotel

and by the number of permanent residents per dwelling :

$-<1$,

$-1-2$,

$-\geq 2$.

The number of water meters monitored for each class are indicated in Fig. 2b.

\subsubsection{Irrigation dataset from field monitoring}

Metering devices were specifically installed to monitor irrigation. At the enduser scale, two radio water meters measured the volumes of irrigation water delivered to a pasture and a private garden, located in Montana-Village (see 
Fig. 1b). Datasets were collected at a bi-weekly time step, with the same methodology as for drinking water meters. The surfaces of the pasture and the private garden were $6700 \mathrm{~m}^{2}$ and $330 \mathrm{~m}^{2}$, respectively. At the distribution scale, an electronic probe (ClaVal e-FlowMeter) was installed upstream of the vineyard area, directly on the irrigation network. This non-invasive meter was simply inserted into an existing control valve, avoiding engineering works on pipes. The irrigation distributed to the vineyard zone was measured at an hourly time step for the 2015 and 2016 irrigation seasons, from April to October.

\subsubsection{Interviews}

Water users were interviewed to document their practices and collect water demand explicative factors:

- 3 municipal water managers,

- 3 professional winegrowers,

- 2 amateur winegrowers,

- 1 residence caretaker,

-1 farmer.

\subsection{Water use regime}

The water use regime is a concept proposed in this study to describe the typical temporal variability of a water use. As for the monthly flow coefficient used for characterising river regimes (the average yearly distribution of river stream flows; Kolupaila and Pardé (1933)), we suggest analysing water use regimes by calculating a regime coefficient $\left(C_{r}\right)$ based on the ratio of water uses to the mean inter-annual use (Eq. 1).

$$
C_{r}=\frac{\text { Water use }}{\text { Mean inter-annual water use }}
$$

In this way, normalised time series were obtained and the seasonal variability could be compared between different types of users. Then, the characteristic temporal signatures were identified and classified into different types of water use regimes. As data were collected from 2015 to 2016, the computation of $C_{r}$ was based on inter-annual values averaged over these two years.

\subsection{Water use density}

The water use density (WUD) is a variable proposed in this work to analyse the intensity of water uses at the spatial scale, with the aim to evaluate water uses with respect to their spatial extent. The water use density was obtained by dividing the water use by the ground-surface occupied by the water user 
(i.e., building's property, irrigated fields) and was expressed in volume per unit area $\left(l / m^{2}\right)$ or in water heights $(m m)$ (Eq. 2).

$$
W U D=\frac{\text { Water use }}{\text { Occupied ground-surface }}
$$

From the monitoring campaign, irrigation distribution volumes were transformed into water use densities by dividing them by the total area of irrigated vineyards. Similarly, raw volumes of drinking water deliveries were divided by the area of cadastral plots corresponding to the monitored buildings (Fig. 1b).

\section{Results and discussion}

\subsection{Drinking water use regimes in Montana}

This section presents the regimes of drinking water uses monitored in Montana. First, the regime of total municipal distribution is analysed (Fig. 2a). Then, the results of the monitoring campaign present regimes of water delivery to the four drinking water use basins (Fig. 2b). A focus is also made on delivery regimes by type of building in the Montana Resort basin (Fig. 3).

\subsubsection{Regime of drinking water distribution}

Drinking water volumes distributed to the entire municipality show high variations throughout the year, and dynamics with various frequencies can be observed (Fig. 2a). First, a long-period signal indicates a monthly seasonal variability in drinking water distribution. The highest demand season occurs in summer (July-August), with the intensity varying each year. We observe a maximum distribution of $3242 \mathrm{~m}^{3}$ /day in mid-July 2015 and a lower maximum the next year, at $2655 \mathrm{~m}^{3}$ /day in late July 2016. The winter high-demand season also varies each year and is composed of two periods: an important demand peak around the New Year period $\left(2575 \mathrm{~m}^{3}\right.$ /day on $31.12 .2014,2098 \mathrm{~m}^{3} /$ day on 30.12 .2015 and $2256 \mathrm{~m}^{3}$ /day on 29.12.2016) and a longer period of high demand (1600-2000 $\mathrm{m}^{3} /$ day) from January to March. Low-demand periods occur in spring (March-April) and autumn (October-early December). Such seasonal regime of drinking water distribution reflects the typical behaviour of mountain tourist resorts, with two high seasons (summer, winter) and two low seasons (spring, autumn). Second, a higher-frequency variability can be observed on a weekly basis and is clearly visible during the mid-seasons (e.g., between March-May 2015 and in January 2016), indicating the increase in occupancy by temporary residents during weekends.

\subsubsection{Regimes of drinking water delivery}

Figure 2b shows cumulative volumes of drinking water delivered to the four drinking water basins monitored. 
In terms of annual volumes, results show that most drinking water $(76 \%)$ is delivered to the Montana Resort basin, as it is the most important agglomeration in the municipality. The water demand seasonality of Montana Resort has therefore the greatest influence on the distribution regime at the municipal scale.

In terms of temporal dynamics, delivery time series indicate that each drinking water basin has a distinctive seasonal regime. The basins of Montana Village and Diogne do not show much seasonal variability. In Corin, important delivery peaks occur in September and October, corresponding to the increase in demand by wineries after the grape harvest. These peaks are even more significant given that the sample accounts for only two wineries. In the tourist resort, deliveries show very high seasonal variability, with a significant peak between July and August and two other peaks at the end of December and in February, with timing similar to the distribution signal. Both winter and summer increases primarily involve hotels, along with houses and apartment blocks with a very low proportion of permanent residents. This high seasonal variability in the resort is explained by the increase in temporary population due to the high number of buildings with temporary residents, compared with the historical villages, where the majority of buildings are houses with permanent residents. In winter, the observed delivery peak can be directly linked to the presence of temporary inhabitants for ski holidays or for the Christmas and New Year periods. The important summer peak cannot be explained solely by the increase in tourist occupancy because it concerns the same categories of buildings as in winter, plus houses with permanent residents. The greatest driver of water demand during this period is watering of private gardens with municipal drinking water, because the resort is not supplied by a separate irrigation network (Reynard and Bonriposi, 2012; Bonriposi, 2013). Apartment blocks with a high proportion of permanent residents do not show any delivery increase in summer, which can be explained by the fact that apartment blocks intended for permanent residency are generally located in the town centre and rarely feature irrigated private gardens.

\subsubsection{Regimes of drinking water delivery in the tourist resort, by type of building}

To highlight the role of the type of habitat on water delivery regimes, the Montana Resort basin was isolated to analyse the distinction between building types and the proportion of permanent inhabitants per dwelling (Fig. 3).

With respect to houses (Fig. 3a), the same high seasonal variability as for the municipal distribution is observed, with two high peaks (summer-winter) and two low seasons (autumn-spring). The higher is the proportion of temporary residents, the stronger is this bi-modal seasonality. Conversely, permanent residences do not show any winter peak. Because of the significant volumes of water delivered in summer for watering gardens, the summer peak for houses 
is higher than the winter peak and is observed for both temporary and permanent residences. This summer peak was more important in 2015, because the region experienced a heat wave in June and July (Calianno and Reynard, 2016), whereas in 2016 June and July were rainy months. These observations highlight garden irrigation's contribution to the mix of drinking water utilisation in the resort.

Apartment blocks represent the largest deliveries in terms of volumes. This was expected, because apartment blocks have multiple households and, therefore, water delivery measured by water meters at the building scale is multiplied by the number of households. Seasonal variability for apartment blocks is not as strong as for houses (Fig. 3b). However, the category with less than one permanent habitant per dwelling shows a marked seasonality, with maxima in summer and winter. Also, summer peaks are less marked for apartment blocks than for houses. This is related to the fact that apartment blocks are located downtown and are less likely to have a garden; if they do, watering is diluted in the water demand of multiple households. For this reason, there is less watering in summer relative to the total amount of drinking water delivered to the block.

Apartment blocks with businesses and hotels are presented in Fig. 3c. Hotels show a bi-modal seasonality similar to those of houses and apartment blocks with a low proportion of permanent residents, but a longer summer peak, forming a plateau in July and August. They are a good example of tourist water delivery seasonality in mountain resorts, with peaks during summer and winter high seasons and almost zero delivery during low seasons, when most hotels are closed. Apartment blocks with businesses have a relatively steady regime, similar to apartment blocks with higher proportions of permanent residents, whereas the regime of businesses is clearly seasonal, because their activity depends on the presence of tourists during high seasons.

Such detailed analysis of delivery regimes underlines the important role of habitat configuration (presence of gardens and lawns, type of building, composition of households) and the proportion of permanent and temporary residents in buildings in the seasonality of water demand. Such factors strongly affect water demand regimes. Moreover, because summer 2015 was characterised by a strong heat wave, it exacerbated water uses related to watering and therefore, the role of irrigated gardens or lawns in the mix of water uses. These results complete the calculations made by Bonriposi (2013) and Reynard et al (2014) on the distribution scale for the entire Crans-Montana resort. 
4.2 Irrigation regimes in Montana

Here are presented the irrigation delivery regimes for the pasture and garden test plots (Fig. 4a) and the irrigation distribution regime for the whole vineyard area (Fig. 4b).

\subsubsection{Regimes of irrigation at the end-user scale (pasture and garden)}

The water meter installed next to the irrigated pasture shows a different delivery regime than for the garden (Fig. 4a).

In 2015, the private garden was watered from April to July, whereas in 2016 it was irrigated from July to September. This is attributable to the heat wave of June and July 2015 and to the humid spring in 2016 (see precipitation in Fig. 4b). In total, $203 \mathrm{~m}^{3}$ were delivered in 2015 and $120 \mathrm{~m}^{3}$ in 2016 .

The irrigation of the test pasture was $375 \mathrm{~m}^{3}$ in 2015 and $692 \mathrm{~m}^{3}$ in 2016 . The seasonality of pasture irrigation differs from year to year. Knowing that the farmer aims to apply an aerial volume of $40 \mathrm{~mm}$, assuming a part of water is lost during aspersion. The pasture was irrigated once in 2015, at the end of June. In 2016, however, the pasture was irrigated three times: first in May, and mostly in July and August. This result can seem illogical because the year 2015 was much hotter and drier than 2016, but it can be explained by the seasonality of precipitation and the agricultural practices. The farmer usually irrigates twice a year, in May and July, because he makes two cuts for hay production. He explained that in 2015, he did not irrigate for the first hay cut in May, because rainfalls occurred some days before. In August 2016, he chose to put cows grazing in the plot after the hay second cut, so he had to irrigate before installing the cows to make the grass grow again.

The difference between the irrigation of pasture and garden is then really a question of seasonality: the pasture is more intensely irrigated, but only once (2015) to three times per year (2016), whereas the private garden is irrigated with lower intensity but daily for the whole summer season.

\subsubsection{Regimes of irrigation at the distribution scale (vineyards)}

The irrigation distribution time series (Fig. 4b) were completed using mean daily temperatures and daily rainfall, measured at the Sierre-Gronde weather station (542 $\mathrm{m}$ a.s.l., 3km from Corin). Results show a high daily variability of distribution for the vineyard area during the irrigation season, along with a high inter-annual variability between 2015 and 2016 .

Three periods of irrigation can be distinguished in 2015. The first was at the end of April (up to $400 \mathrm{~m}^{3}$ /day over 5 days) and was primarily related to the watering of young grape plants. A second period, longer but with the 
same intensity (100 to $400 \mathrm{~m}^{3} /$ day over 30 days), occurred in June. Between these two periods there was no irrigation, due to two significant rainfall events in May (Calianno and Reynard, 2016). The main vineyard irrigation season occurred from 29 June to 10 August, with values up to $2600 \mathrm{~m}^{3} /$ day. The intensity of this irrigation period is a minimum because the flow-meter was blocked twice in July. The volume of irrigation water used during these gaps could be estimated through interviews with local winemakers and water managers. They were set to $1400 \mathrm{~m}^{3}$ /day for the first gap and $1000 \mathrm{~m}^{3} /$ day for the second gap. After this intense irrigation period, the first week of August still showed important distributions, but below the values of July (from 600 to $1500 \mathrm{~m}^{3}$ /day). In 2016 the total annual distribution $\left(4^{\prime} 845 \mathrm{~m}^{3}\right)$ was lower by a factor of 10 compared to $2015\left(49^{\prime} 894 \mathrm{~m}^{3}\right)$. These two years are two opposite examples of vineyard climate: 2015 was a hot and dry summer, whereas 2016 was a humid and relatively mild summer.

Such results give insights on vineyard irrigation practices in Montana. Local winegrowers believe that 30 to $50 \mathrm{~mm}$ of water are needed for a good watering. They irrigate once, or exceptionally twice per season. Examining the results, the maximum distribution rates in $2015\left(2600 \mathrm{~m}^{3}\right.$ /day, corresponding to 3.5 $\mathrm{mm}$ /day, relative to the total vineyard area) seems very low given the summer heat wave. A reason could be that some plots were not irrigated. Another reason is that not all vineyard plots are irrigated at the same time, given that the municipality enforces an irrigation calendar from July to August, allowing three irrigation rounds per vineyard plot distributed through this period. Considering the total irrigation during the 2015 season $(66.7 \mathrm{~mm})$, we can estimate that the equivalent of all vineyard plots were irrigated at least once.

2016 was a very humid season. According to our field observations and interviews, there was almost no irrigation of vineyards that year, except for plots with young grapes. The vast majority of irrigation water in 2016 in this area was used for public green spaces (football field, flowerbeds) and private gardens.

4.3 Water use density of drinking water and irrigation in Montana

This section presents the annual gross volumes for water uses monitored at the municipal scale (distribution for municipal drinking water and vineyard irrigation) and the water use densities of all uses in 2015 and 2016 (Fig. 5a).

\subsubsection{In terms of gross volumes}

The annual drinking water distribution in Montana was 618'501 $\mathrm{m}^{3}$ in 2015 and $615430 \mathrm{~m}^{3}$ in 2016, whereas the irrigation distribution to the vineyard area was $49^{\prime} 894 \mathrm{~m}^{3}$ in 2015 and $4^{\prime} 845 \mathrm{~m}^{3}$ in 2016 . When looking at the annual scale, drinking water distribution is by far higher than water used for irrigation. 
Drinking water distribution is constant between 2015 and 2016, whereas there is an important inter-annual variability of vineyard irrigation, related to the seasonal meteorological context.

\subsubsection{In terms of water use density}

During the 2015 heat wave, the irrigated private garden represented the highest annual water use density, with $615 \mathrm{~mm}$ delivered. This value is very high as it corresponds to the annual rainfall average $(692 \mathrm{~mm})$ in the area (Calianno and Reynard, 2016). In Montana Resort the density of drinking water deliveries relative to cadastral surfaces is also high $(566 \mathrm{~mm})$. Values are lower for the other drinking water basins: $286 \mathrm{~mm}$ in Corin, $256 \mathrm{~mm}$ in Montana Village and $134 \mathrm{~mm}$ in Diogne. In comparison, the densities for the irrigation of the vineyard area $(67 \mathrm{~mm})$ and the pasture test plot $(56 \mathrm{~mm})$ are very low.

In 2016, which had a fresher and more humid summer, water deliveries to the resort represent the highest densities $(569 \mathrm{~mm})$, because the garden was less irrigated that year $(364 \mathrm{~mm})$. The vineyard area was also much less irrigated than in 2015 ( $7 \mathrm{~mm})$, whereas water delivered to the pasture almost doubled $(103 \mathrm{~mm})$. Aerial annual values for Montana Village and Diogne are almost identical to 2015, and in Corin, they are higher $(374 \mathrm{~mm})$.

These results indicate that most of the gardens and lawns in the resort are irrigated whatsoever the climatic conditions (moreover, with drinking water), whereas there was an important decrease in irrigation for the private garden in the historic village and for vineyards with the fresher 2016 weather conditions. With respect to pasture irrigation, it seems to be more influenced by the agricultural practices than by climate conditions.

The irrigation of the garden shows a very high water use density, when compared to pastures. This result is interesting, because it contradicts the representations of local inhabitants, who regularly note the large amounts of water used by the farmers in the municipality. Because farmers' sprinklers are big and irrigate large surfaces, they are more visible than small, private garden sprinklers or vineyard sprinklers, which are spread over the vineyard area. Therefore, pasture irrigation sticks in people's minds as an important water use. In the end, in terms of water use density, garden watering is a much more important water use than was expected and it seems to be quite underestimated by the local community. Nevertheless, because irrigated pastures cover large surfaces, the overall need for pasture irrigation at the municipal scale is still relatively high, as Bonriposi (2013) and Reynard et al (2014) suggest, throughout the region. 
4.4 Synthesis of water uses regimes in Montana

In terms of volumes at the annual time scale, the irrigation of vineyards and pastures seems insignificant compared to drinking water uses, but considering that the vineyard covers a large area and that the irrigation regimes are highly seasonal, these quantities of water demand can exert significant additional pressure on the water resource system at precise moments of the year, especially during dry and hot periods. To analyse the role of water use seasonality, a synthesis graph (Fig. 5b) plots all of the regimes monitored: deliveries to the drinking water basins (Montana Resort, Montana Village, Diogne, Corin), deliveries to the irrigated garden and pasture and distribution to the irrigated vineyard. The regimes are computed using Eq. 1 over the monitoring period (2015-2016) to represent the average seasonality of water uses on a single standardised year.

Strong differences in temporal variability are observed between water uses: drinking water is distributed constantly throughout the year, whereas irrigation occurs only during the summer months. The graph also indicates that water demand peaks for all water uses coincide in the same period in July. In Montana's resort, the summer high tourist season is the period of the year when there is a cumulative demand for both irrigation and drinking water, whereas during the winter high tourist season, higher demand for drinking water is compensated by an absence of demand for irrigation. The other villages are less subject to temporal variability, except the vineyard village (Corin), where the autumn grape harvest plays a role in the water regime.

\section{Conclusion}

This article aimed at developing the water use cycle framework (Calianno et al, 2017) at the operational level with a monitoring campaign of water uses at the end-user scale in the municipality of Montana (Switzerland). It provided the first irrigation monitoring in the area and a classification of drinking water data according to their spatial distribution, the type of building and the permanency of habitat. In parallel, interviews with water users and managers helped us to integrate the water user practices and the water management rules in the analysis. The monitoring data were studied using the concepts of water use regime, describing the seasonality of water uses with standardised time-series and the concept of water use density, expressing the territorial footprint of water use, per unit area. These tools provide a framework giving a more accurate view on the diversity and seasonality of water uses in mountain territories: data on water uses are collected at local scale and classified by users and temporal resolution go from bi-weekly to daily time steps.

The water use regime proved to be a useful concept to assess differences in demand seasonality at the intra-annual scale, knowing that water shortages in 
tourist mountain regions mostly occur for short time periods. Previous studies also analysed water use habits according to the habitat and socio-economic factors (March et al, 2015; Morote et al, 2016), but on an annual temporal resolution. In this work, water use regimes highlighted water demand patterns from different categories of habitat at bi-weekly time step: temporary and permanent residents; houses, apartment blocks and hotels.

Moreover, the roles of each different user behaviour in the alpine resort's global drinking water use dynamic, decribed qualitatively or with monthly data in previous studies (Paccard, 2010; Bonriposi, 2013; Magnier, 2013; Leroy, 2015) are here classified and quantified at bi-weekly time-scale through the classification of water use regimes. This local scale approach provides benchmark water use values for regional studies, in which high-frequency water demand variability are often hidden when mean annual data are used (e.g., 120 $\mathrm{m}^{3}$ /year/household) (Barbier and Montginoul, 2013) or when unit water demand values (e.g., 150 litres/day/person) are obtained by down-scaling annual or monthly data simply dividing by the number of days in a year or in a month (Rinaudo, 2015; Sax et al, 2016). Nevertheless, the number of temporary residents, responsible for most of the seasonality of drinking water distribution in tourist resorts remain difficult to estimate, as (Leroy, 2015) also noted.

The water use density gives a new perspective on the spatial intensity of water uses in mountain territories. The highest densities observed in Montana concern the use of drinking water in the tourist resort and the irrigation of the private garden, whereas the lowest densities are for the irrigation of pastures and vineyards. This an interesting result because these two latter uses are commonly considered as the most important by the local people, due to the impressive aspect of sprinkle irrigation.

Applied at the operational level, water use regimes and densities give a quantitative view on urban water socio-technical systems (Bos and Brown, 2012) and on the hydrosocial cycle (Linton and Budds, 2014) when taking into account all water uses at the territorial scale. Such monitoring at the local scale constitutes the kind of dataset that should be used to develop and validate integrative water management prospective models that aim to evaluate the pressure on water resources at the regional scale and the satisfaction rate for future water uses (Milano et al, 2013, 2015; Collet et al, 2015; Grouillet et al, 2015; Leroy, 2015; Fabre et al, 2016).

Concerning the monitoring, a balance between spatial and temporal accuracy must be found. On the one hand, using water demand determining factors at a rough spatio-temporal resolution enables efficient assessments, but only at large scales. On the other hand, the integration of all components of water demands at high resolution produces extremely detailed models, which, although getting closer to the complexity of human-water systems, may be too elaborated to be applied by stakeholders and difficult to apply on large surfaces due to data collection difficulties. 
Acknowledgements We would like to thank Olivier Bonvin and Bernard Cordonier of the Technical Service of Montana Municipality, and Daniel Rey, of the Municipalites of CransMontana Association (ACCM) for their support and transmission of data, along with the municipal technicians José Anchel Rivodigo and Claude Meyrat, for the help in the fieldwork and their knowledge of Montana's water networks. Thanks to Daniel Ré, Steve Werren (Cla-Val) and Sandro Barth (GWF) for their support with monitoring devices and water meters. We also acknowledge the water users interviewed during this work for their personnal contribution to the monitoring exercise: Frédéric Bonvin, Yves-Roger Rey, Jean-Daniel Rey, Christophe Rey, Ismaël Bonvin, Arsène and Francoise Borgeat, Pierre-Louis Mudry, Noël and Placide Cordonier, Corinne Ançay, Christian Blazer, Steeve Maillard and Stéphane Emery. Finally, we thank Georges-Marie Saulnier, André Musy and Aude Soureillat for their input on this research, and Jean-Michel Fallot, for his help in climate data processing.

\section{References}

Allen RG, Pereira LS, Raes D, Smith M (1998) Crop evapotranspiration. Guidelines for computing crop water requirements. Food and agriculture organisation (FAO), Rome

Barbier R, Montginoul M (2013) Avant-propos : $120 \mathrm{~m}^{3}$, le consommateur d'eau en question. Sciences Eaux et Territoires 10:2-3

Bonriposi M (2013) Analyse systémique et prospective des usages de l'eau dans la région de Crans-Montana-Sierre (Suisse). PhD thesis, Université de Lausanne

Bos J, Brown R (2012) Governance experimentation and factors of success in socio-technical transitions in the urban water sector. Technological Forecasting and Social Change 79:1340-1353

Calianno M, Reynard E (2016) Influence des facteurs climatiques sur la distribution de l'eau d'irrigation dans le vignoble de Montana (Suisse). In: Fallot JM, Joly D, Bernard N (eds) Climat et pollution de l'air. Actes du XXIXe Colloque de l'Association Internationale de Climatologie, Besançon, France, pp 439-444

Calianno M, Reynard E, Milano M, Buchs A (2017) Quantifier les usages de l'eau : une clarification terminologique et conceptuelle pour lever les confusions. Vertigo URL http://journals.openedition.org/vertigo/18442

Collet L, Ruelland D, Borrell-Estupina V, Dezetter A, Servat E (2015) Water supply sustainability and adaptation strategies under anthropogenic and climatic changes of a mesoscale Mediterranean catchment. Sci Total Environ 536:589-602

Fabre J, Ruelland D, Dezetter A, Grouillet B (2016) Sustainability of water uses in managed hydrosystems: human- and climate-induced changes for the mid-21st century. Hydrol Earth Syst Sc 20(8):3129-3147

Gargano R, Tricarico C, Granata F, Santopietro S, de Marinis G (2017) Probabilistic models for the peak residential water demand. Water 9(6):417

Gössling S, Peeters P, Hall CM, Ceron JP, Dubois G, Lehman LV, Scott D (2012) Tourism and water use: Supply, demand, and security. An international review. Tourism Management 33:1-15 
Grouillet B, Fabre J, Ruelland D, Dezetter A (2015) Historical reconstruction and 2050 projections of water demand under anthropogenic and climate changes in two contrasted Mediterranean catchments. J Hydrol 522:684696

Gurung T, Stewart R, Beal C, Sharma A (2016) Smart meter enabled informatics for economically efficient diversified water supply infrastructure planning. Journal of Cleaner Production 135:1023-1033

Haque M, de Souza A, Rahman A (2017) Water demand modelling using independent component regression technique. Water Resour Manage 31(1):299 312

Klug H, Dabiri Z, Hochwimmer B, Zalavari P (2012) Assessing drinking water consumption by inhabitants and tourists in the Alps using a WebGIS for information distribution. International Journal of Biodiversity Science, Ecosystem Services and Management 8(1-2):50-70

Kolupaila S, Pardé M (1933) Le régime des cours d'eau de l'Europe orientale. Rev Geogr Alp 21(4):651-748

Leroy E (2015) Proposition d'interface science-société pour la gestion intégrée de la ressource en eau dans un contexte de changements climatiques. $\mathrm{PhD}$ thesis, Université de Grenoble

Linton J, Budds J (2014) The hydrosocial cycle: defining and mobilizing a relational-dialectical approach to water. Geoforum 57:170-180

Magnier E (2013) Neige artificielle et ressource en eau en moyenne montagne : impacts sur l'hydrosystème. Les exemples d'Avoriaz (France) et de Champéry (Suisse). PhD thesis, Université Paris IV Sorbonne et Université de Lausanne

March H, Hernandez M, Sauri D (2015) Assessing domestic water use habits for more effective water awareness campaigns during drought periods: A case study in Alicante, eastern Spain. Natural Hazards and Earth System Sciences 15(5):963-972

Milano M, Ruelland D, Dezetter A, Fabre J, Ardoin-Bardin S, Servat E (2013) Modeling the current and future capacity of water resources to meet water demands in the Ebro basin. J Hydrol 500:114-126

Milano M, Reynard E, Köplin N, Weingartner R (2015) Climatic and anthropogenic changes in western Switzerland: impacts on water stress. Sci Total Environ 536:12-24

Morote AF, Hernandez M, Rico AM (2016) Causes of domestic water consumption trends in the city of Alicante: Exploring the links between the housing bubble, the types of housing and the socio-economic factors. Water $8(374): 1-18$

Nazemi A, Wheater H (2015) On inclusion of water resource management in earth system models - part 2: Representation of water supply and allocation and opportunities for improved modeling. Hydrol Earth Syst Sc 19(1):63-90

Paccard P (2010) Gestion durable de l'eau en montagne: le cas de la production de neige en stations de sports d'hiver. $\mathrm{PhD}$ thesis, Université de Savoie

Reynard E, Bonriposi M (2012) Water use management in dry mountains of Switzerland. The case of Crans-Montana-Sierre area. In: Neményi M, 
Balint $\mathrm{H}$ (eds) The impact of urbanisation, industrial, agricultural and forest technologies on the natural environment., Nyugat-magyarorszagi Egyetem, pp 281-301

Reynard E, Bonriposi M, Graefe O, Homewood C, Huss M, Kauzlaric M, Liniger H, Rey E, Rist S, Schädler B, Schneider F, Weingartner R (2014) Interdisciplinary assessment of complex regional water systems and their future evolution: how socioeconomic drivers can matter more than climate. WIREs Water 1(4):413-426

Rico-Amoros AM, Olcina-Cantos J, Sauri D (2009) Tourist land use patterns and water demand: Evidence from the Western Mediterranean. Land Use Policy 26(2):493-501

Rinaudo JD (2015) Long-term water demand forecasting. In: et al QG (ed) Understanding and managing urban water in transition, Global Issues in Water Policy 15, Springer, pp 239-268

Romano G, Salvati N, Guerrini A (2016) An empirical analysis of the determinants of water demand in Italy. Journal of Cleaner Production 130:74-81

Saulnier GM, Castaings W, Hohenwallner D, et al (2011) Monitoring and modelling of mountain water resources - a short guideline based on the results of Alp-Water-Scarce. Tech. rep., Alp-Water-Scarce (Interreg IV B, Alpine Space Programme, project 5-1-3-F)

Sax M, Schmude J, Dingeldey A (2016) Water demand in tourism facilities. In: Mauser W, Prasch M (eds) Regional assessment of global change impacts, Springer, pp 153-158

Vallès-Casas M, March H, Sauri D (2017) Examining the reduction in potable water consumption by households in Catalonia (Spain): Structural and contingent factors. Applied Geography 87:234-244

Vanham D, Millinger S, Pliessnig H, Rauch W (2011) Rasterised water demands: methodology for their assessment and possible applications. Water Resour Manage 25:3301-3320 
1

2

3

4

5

6

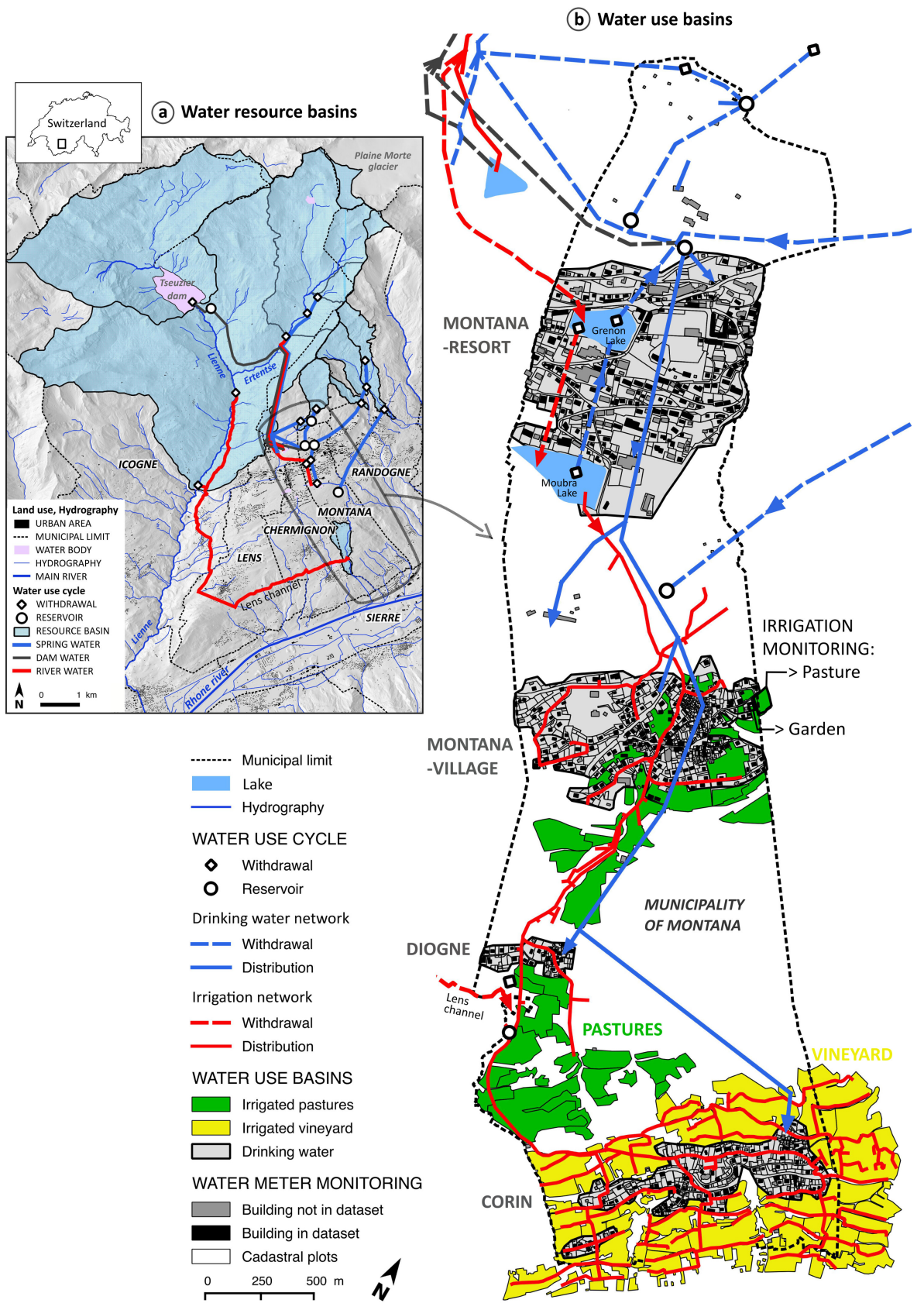

Fig. 1 Water use cycle in Montana: (a) withdrawals from resource basins, (b) distribution to water use basins 
(a) DISTRIBUTION OF MUNICIPAL DRINKING WATER

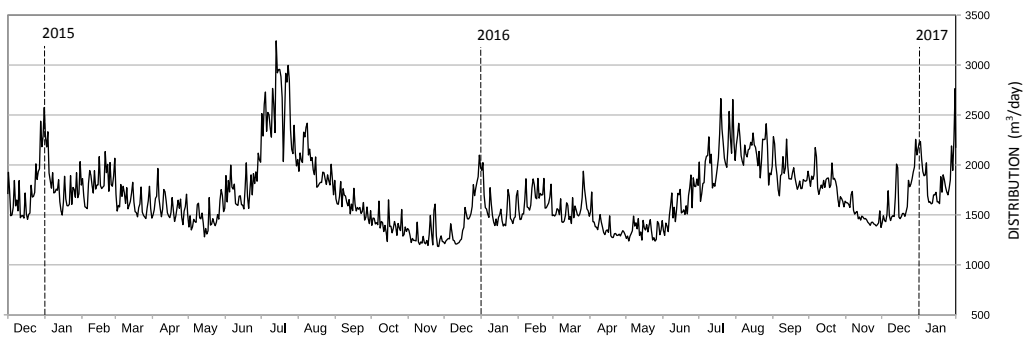

(b) DELIVERY TO DRINKING WATER USE BASINS, BY CATEGORY OF USER
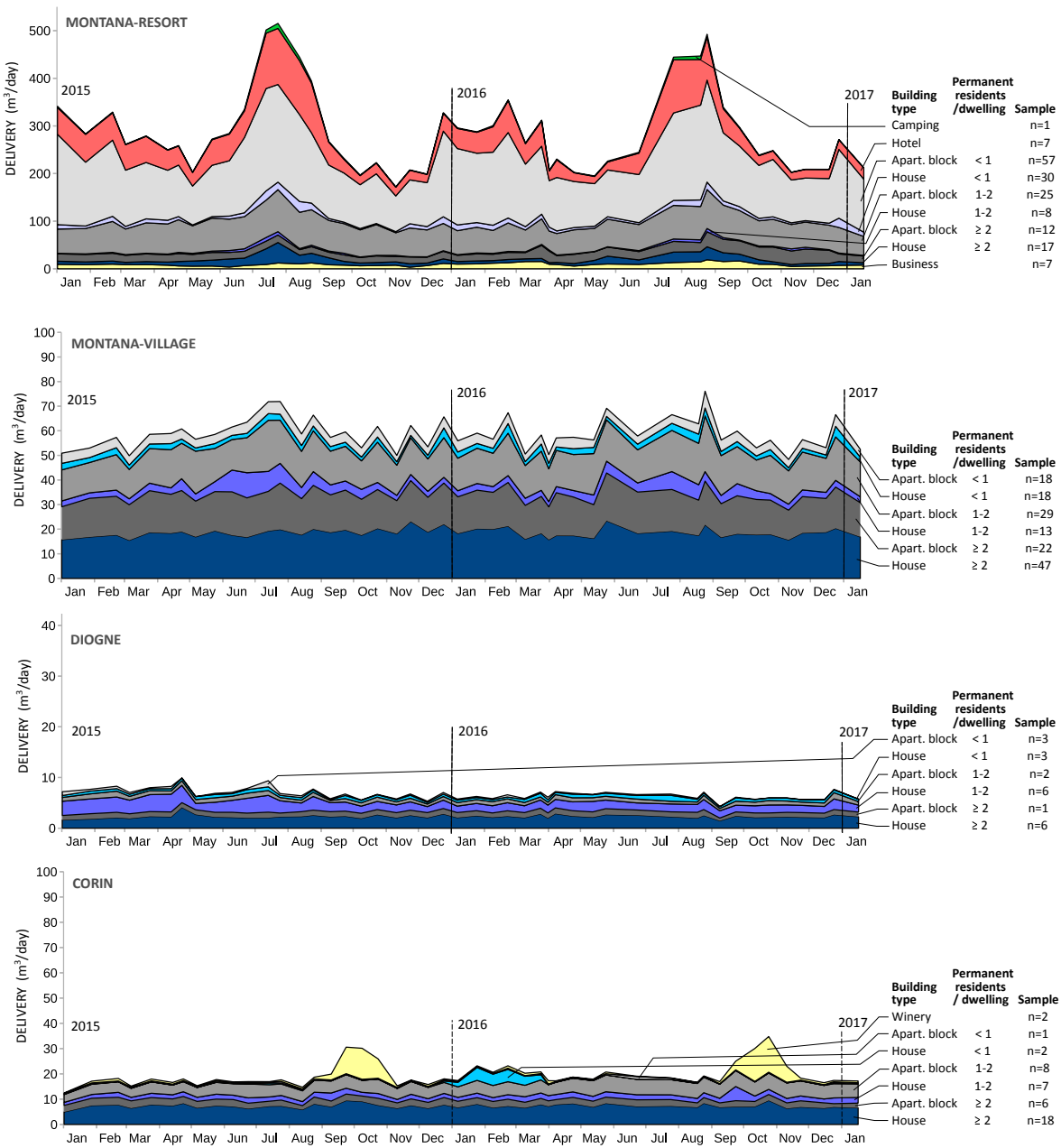

Fig. 2 Water use regimes in Montana (2015-2016): (a) drinking water distribution, (b) cumulative drinking water deliveries to water use basins, by category of user 
(a) Houses

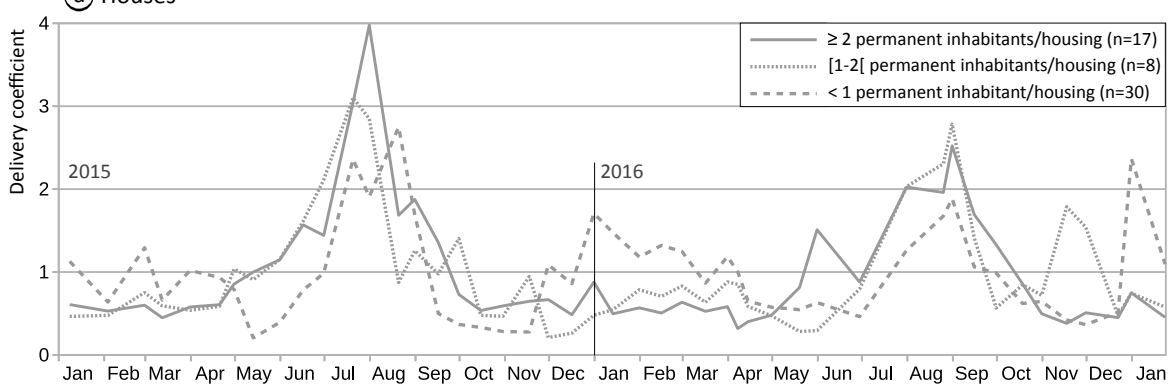

(b) Apartment blocks
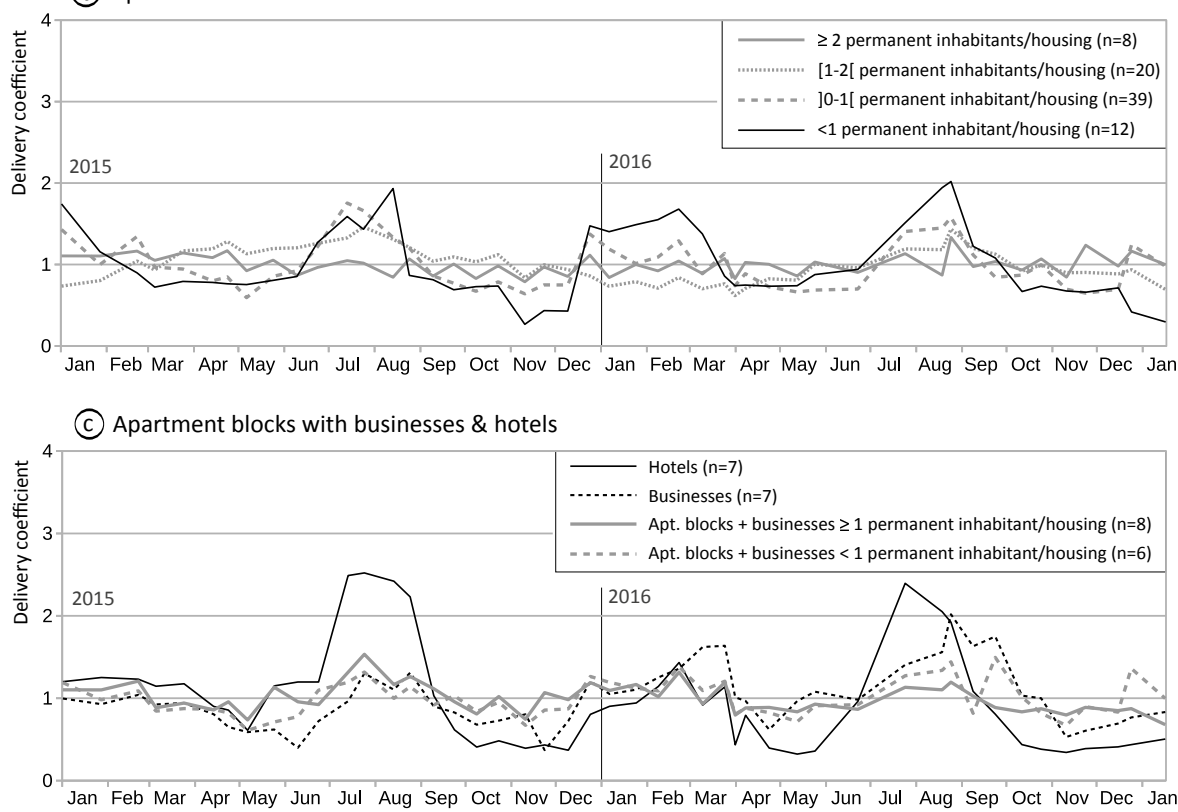

Fig. 3 Regimes of drinking water delivered to different categories of users in the Montana tourist resort: (a) Houses, (b) Apartment blocks, (c) Apartment blocks with businesses and hotels 


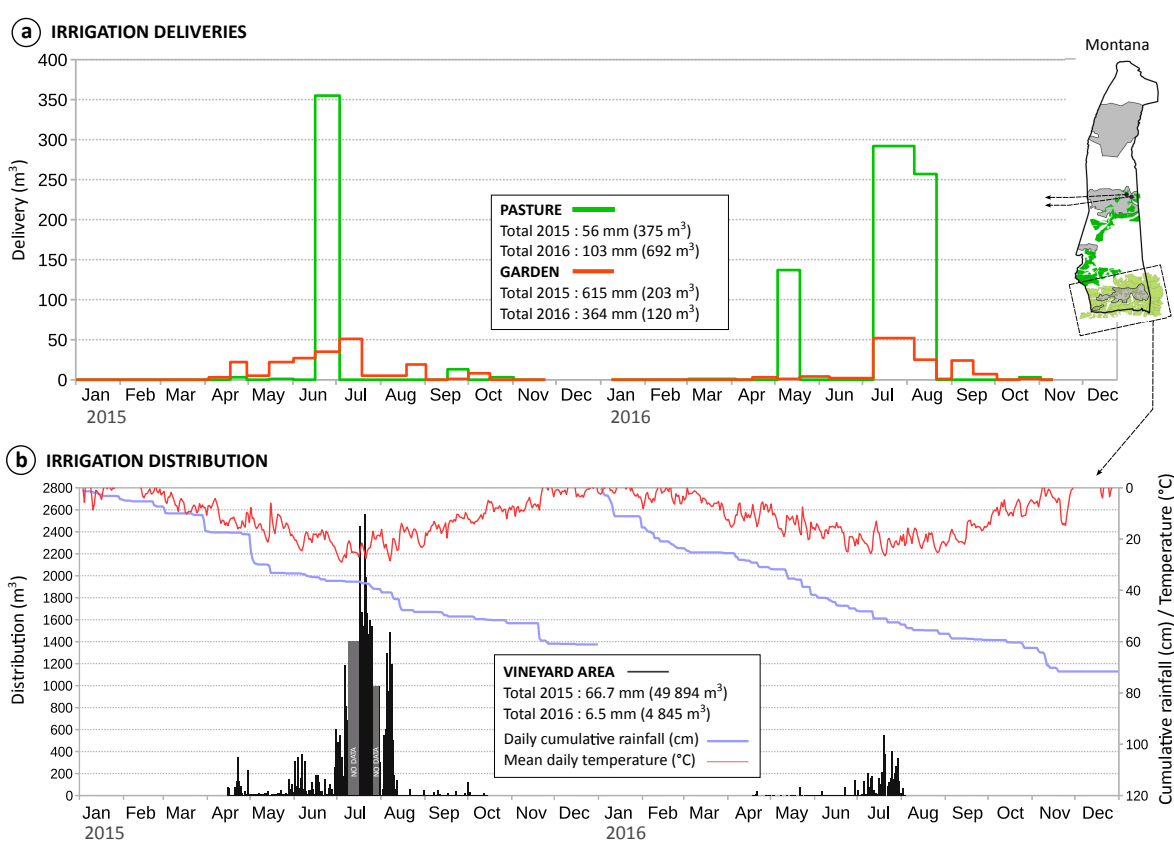

Fig. 4 Water use regimes in Montana (2015-2016): (a) irrigation water delivered to the pasture and garden test plots, (b) irrigation water distributed to the vineyard area. Grey bars in (b) indicate periods with missing data. 
1

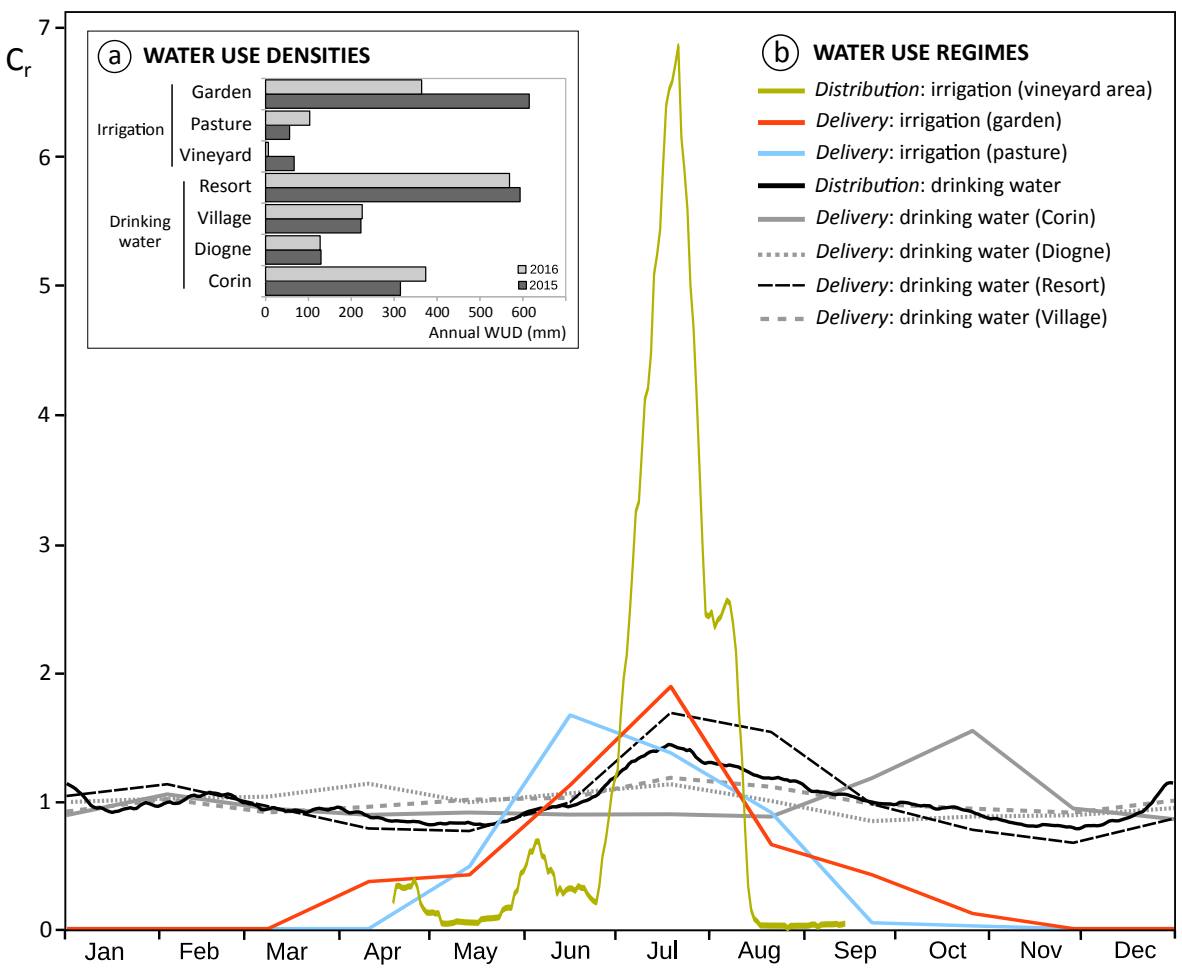

Fig. 5 Summary of water use dynamics in Montana (2015-2016): (a) water use densities, (b) water use regimes 